\title{
The Analysis of Moral Value Of High School Level Teenagers in Magelang
}

\author{
Purwati, Septiyati Purwandari, Ari Supriyatno, Novi Nur Yuhenita, Mardiana \\ \{\} \\ Universitas Muhammadiyah Magelang, Magelang, Indonesia ${ }^{1,2,3,4,5}$
}

\begin{abstract}
The purpose of this study is to analyze the problems occur in teenagers' moral values at the High School level in Magelang. The type of research used is qualitative research. The method used is in the form of questionnaire and interview with high school Counseling and Guidance teachers in the city of Magelang. The instrument used is an open questionnaire that can be filled in various ways, according to the real conditions encountered by the Counseling and Guidance teachers. The result obtained by the research conducted in Magelang shows that the low moral values of teenagers at the High School level are honesty, responsibility, and social care.
\end{abstract}

Keywords: Teenagers' Moral, Guidance and Counseling.

\section{Introduction}

In the current era of globalization, the environment has various definitions. A person can easily find the atmosphere he/she likes so that it can bring positive effects or, vice versa, negative effects. Teenagers are the most vulnerable generation to negative influences that cause moral decadence [1]. Adolescence is often associated with myths and stereotypes about disorder and irregularities. Developmental tasks in adolescence accompanied by the development of intellectual capacity, stress and new expectations experienced by teenagers make them susceptible to interference. These disorders are in the form of thoughts, feelings and behavioral disorders. So, it is common for teenagers to take risks by doing something in the form of juvenile delinquency [2]. Various problems regarding the concepts and applications of the values, morals, attitudes, and religion of students become a concern of educators, scholars, community leaders, and parents. Moreover, the challenges that occur in the era with globalization and Global Village slogan make teenagers easily persuaded by the glittering of the hedonistic, consumerist world, and the night life that increasingly distracts children from values, morals, religious attitudes and behavior. We often hear news about criminal acts committed by students [3].

Teenagers, in the transition period from childhood to adulthood, require special attention. At this time they began to look for their own identities. This period is often referred to as the rise of personality [4]. The term 'teenagers' or 'adolescent' comes from the Latin word 'adolescere' which means 'grow' or 'grow into adulthood'. Adolescence is an important period because there is a transition from childhood to adulthood. Happiness in adolescence lies in the success of carrying out developmental tasks that emphasize more on overcoming childish behavior patterns towards adult behavior patterns [4]. Adolescence is a time when a child experiences quite rapid development and emotions that are always tempestuous. Adolescence 
is a potential as well as a problem that must get serious attention, both by parents and educators. Positive emotions that emerge such as pleasure, love, and happiness are positive potentials that can lead teenagers to positive behavior as well. On the other hand, negative emotions such as anger, disappointment, fear, anxiety, hate are emotions that can trigger the emergence of various teen problems. Understanding teenagers and their emotional development becomes very important to help them develop their potentials, as well as seeking solutions to the problems they face [5]. Teenagers who show behavior in accordance with the applied norms and values, they are said to have morality. Whereas, teenagers who exhibit behavior which are contrary to the applied norms and values, then they are said to carry out immoral actions [6]. The development of teenagers is the increase in the ability and the body function in more complex structures and functions in an orderly and predictable pattern, as a result of maturity. The differentiation of structure and function of body organs also affect the aspects of adolescent development. One of the aspects of development that experiences change is the moral aspect [7].

Juvenile delinquency is usually carried out by teenagers who fail in undergoing the process of mental development, both during adolescence and childhood. A recent worrying fact is the courage of teenagers to violate moral norms. There are teenagers who even consider that the relation between men and women does not need to be limited and controlled by parents. This kind of delinquency is usually followed with acts that disturb the community. In adolescence, there is an unrestrained emotional upheaval, for example in an election campaign where the turmoil is supported by vitality and the enthusiasm of youth (mostly teenagers) that is out of control [8]. In the era of globalization, the freedom to socialize among teenagers is worrying. We often find teenagers with deviant behavior regardless the surroundings. Many of them start to imitate the dating style of foreign people (western), which is associated with promiscuity

To make children own good morals and avoid moral violation, it takes early development to the children within a family and cooperation between family, school, and community. How good moral education in the family is, without the support of schools and the community, it is difficult for children to have good morals. Likewise, moral education in schools, without the support of family and society, is difficult for children to have good morals. Thus, these three types of institutions cannot be separated and must support each other [9].

One of the things that disturbs and is often talked about by society is moral problem [4]. Morality itself has a definition. Moral, attitude and moral values come from the Latin word "mores" which means procedures, habits and customs. Moral attitude means behavior that is in accordance with the moral code of social groups, which is developed by moral concepts. What is meant by a moral concept is the regulation of behavior that has become a habit of members of a culture. This moral concept determines the behavior patterns expected from all group members [10].

Moral as a standard that arises from religion and social environment of teenagers provides the absolute concepts of good and bad, appropriate and inappropriate. On the one hand, teenagers will not simply accept those concepts, but contrast them with their self-image and cognitive structure. With respect to cognitive structure, teenagers judge morals with practical tendencies. Teenagers consider the right thing by the suitability between ideal and practice. The implementation of moral and values are not in accordance with daily life. Morals lack of binding power for teenagers. Moreover, cheating and injustice that is seen daily by teenagers creates conflict within themselves. The strong conflicts often bring anxiety to teenagers. They often blame leaders as people who are no longer useful, to be replaced with more valuable activities [4]. 
Moral behavior, in a broad sense, is the consequence or result of moral knowing and moral feeling. If someone has the moral qualities of intellectual and emotion, then he/she can predict that he/she will do what is known and felt. Conceptually, moral behavior must have competence regarding moral considerations. This moral consideration competence is a necessity for the emergence of moral actions [7].

Juvenile delinquency occurs in many places throughout Indonesia, one of which is the city of Magelang in Central Java Province. Many cases of juvenile delinquency that occur and in handling them sometimes it has to involve the police. The variety of moral values that teenagers must possess encourages researchers to conduct research by analyzing the moral values of teenagers, which has experienced a decline. The study was conducted by involving teachers of Counseling Guidance for high school level in which teenagers were as their student groups.

\section{The Research Method}

The type of research used was qualitative research with the questionnaire and interview methods. Qualitative research was chosen in this study because it was hoped that through this research a lot of information was obtained from the field, without any data manipulation or change so that the researcher obtained the original data from the research. The process of conducting research was carried out in several stages in sequence. These stages contained various activities to achieve certain goals in the research process. The stages of the research can be observed in Figure 1.
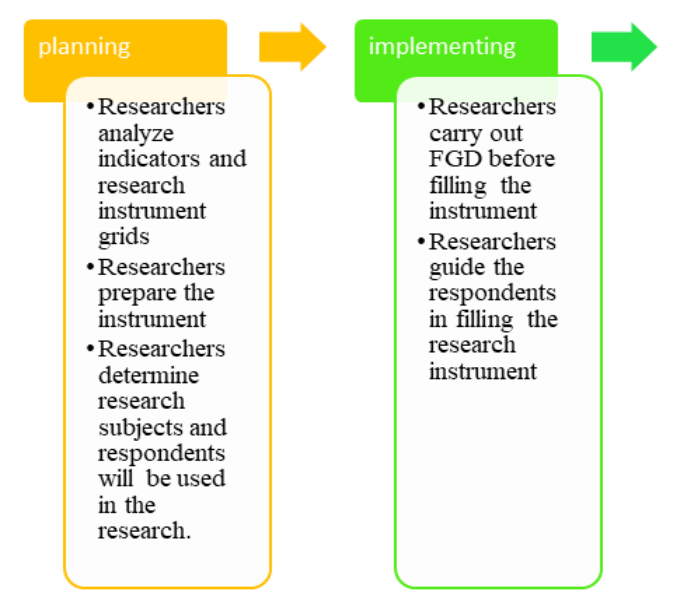

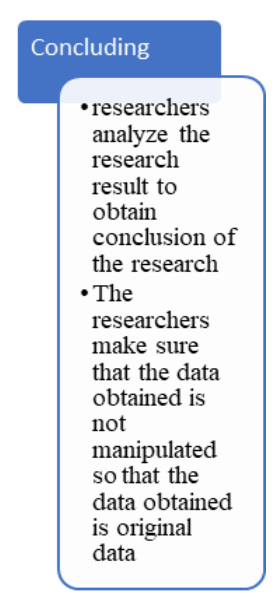

Fig. 1. The Research Flow

This research was conducted using the Counseling Guidance teachers in the city of Magelang as the subject. The study was conducted in the period of June-September 2018. The instrument used was a questionnaire to analyze teenagers' behavioral problems. Indicators used were in the form of sexual behavior, knowledge of character, problems of social moral behavior, problem solving skills, social competence, relationships with others, feelings of attachment to school, academic achievement, communication competence, and attitudes to the teachers. 


\section{The Research Result}

In the current era of globalization, the development of information is widespread and can be accessed very easily. This causes a variety of negative values or elements that are no longer able to be filtered so that they easily influence the thoughts and character of the generation (present generation). This raises concerns about the problem of identity that is related to the decline of religious values, nationalism, the socio-cultural value of the nation and the development of individual morality. This raises anxiety so that it requires a more serious approach to strengthen the identity of the younger generation through national character and cultural education [11].

The main problem that is very prominent now is the vague values in the eyes of the younger generation. They face various contradictions and various moral experiences which cause them to be confused to choose the good. This is obvious in those who are in their teens, especially those who live in big cities in Indonesia [4]. Humans, as social beings, need support from their social environment. Social support is assistance provided by people that is meaningful to individuals that involves emotional, informative, instrumental, and assessment aspects. The existence of good social support from family, friends and teachers will cause teenagers to know that other people pay attention to, appreciate, and love them. Social support will also provide information for teenagers on how to behave well in social interactions [4]. Education is an effort to shape the expected moral development. Education is often defined from practices used by schools and teachers to influence student learning and development [7].

Character education aims to develop the values that shape the nation's character, namely Pancasila, including: (1) developing the students' potential to be kind-hearted, good-minded, and well-behaved humans; (2) building a nation that has the character of Pancasila; (3) developing the potential of citizens to be confident, proud of their nation and country and love humanity [12]. Character education aims to improve the quality of educational processes and results that lead to the formation of the noble character of students in a comprehensive, integrated and balanced manner, in accordance with the graduates' competency standards in each education unit.

Moral behavior is the product of two other characters. If someone has good intellectual and emotional moral qualities, he/she has the possibility of doing actions that according to his/her knowledge and feelings are the right actions. But sometimes people can be in a situation where they know what to do, feel they have to do it, but still can't translate those feelings and thoughts into action [11].

One of the development tasks that must be carried out by teenagers is to learn the things that are expected by the group and then shape their behavior to meet the expectations of their social environment without continuing to be guided, monitored, encouraged and threatened with punishment as experienced in childhood [13]. Based on research carried out on the Counseling and Guidance teacher for high school level, the moral behaviors of teenagers in the low category are three, namely honesty, responsibility, and social care.

An honest person is someone who has integrity. Integrity is a basic trait that a person has as a whole in the sense that his personality is not boxed but that he behaves and acts as himself, consequently and equally from various dimensions of life according to a personality pattern that does not force him to constantly hide his true face [14]. Honest, in a narrow sense, is the conformity of verbal speech with reality. In a more general sense, it is the physical and mind conformity. Honesty, when interpreted in language is to acknowledge, say, or provide 
information that is in accordance with truth and reality. An honest attitude or honesty of a person is usually associated with conscience and recognition [12].

Next is social care. This concern is sensitivity to the social environment, through behavior, actions, and words. The character value of social care is basically one of the many human values. The word humanity, refers to its properties, consists of physical and spiritual with all its characteristics, both of which are one entity. It is endowed with a nature that is focused on its own interests (individual nature), and traits that are aimed at the interests of others, the general public and the state (social nature). Both of these traits are competing for power so that these two traits need to be controlled and developed in harmony, so as not to cause behavioral deviations. [15]. By definition obtained from respondents, data related to low youth morale can be observed in table 1 below.

Table 1. Description of research results based on the respondents.

\begin{tabular}{|c|c|c|c|}
\hline No & Character & $\begin{array}{c}\text { Description } \\
\end{array}$ & Indicator \\
\hline 1 & Honest & $\begin{array}{l}\text { Behavior that is based on } \\
\text { someone's effort to make him/her } \\
\text { self a person who can always be } \\
\text { trusted in words, actions and work }\end{array}$ & $\begin{array}{l}\text { 1) Do not use convoluted words } \\
\text { in answering question } \\
\text { 2) Speak truly } \\
\text { 3) Do not cheat in exam }\end{array}$ \\
\hline 2 & Social Care & $\begin{array}{l}\text { Attitudes and actions that always } \\
\text { want to provide assistance to other } \\
\text { people and communities in need }\end{array}$ & $\begin{array}{l}\text { 1) Save friends from danger } \\
\text { 2) Share food with friends } \\
\text { 3) Accompany a sick friend go } \\
\text { home } \\
\text { 4) Ease the teachers' burden }\end{array}$ \\
\hline 3 & Responsible & $\begin{array}{l}\text { Attitude and behavior of a person to } \\
\text { carry out his/her duties and } \\
\text { obligations, which he should do to } \\
\text { himself, society, environment } \\
\text { (natural, social, and cultural), the } \\
\text { country and The One Almighty God }\end{array}$ & $\begin{array}{l}\text { Carry out daily chores } \\
\text { Do assignment }\end{array}$ \\
\hline
\end{tabular}

The respondents also said that alternatives that can be used to deal with the low level of 3 teenagers' moral values are in the form of group learning while playing (Village learning friends), behavioral or more to changes in student behavior, and peer counseling. These three alternatives appear based on the experience of the respondents as they become counselors.

It is very important that education is continued until moral feeling. Moral feeling is another aspect that must be instilled in students, which becomes the source of energy within human beings to act according to moral principles. There are six emotional aspects that must be felt by a person to become a person with moral or character, namely conscience, self esteem, empathy (feeling the pain of others), loving the good, self control (able to control themselves) and humility (humility). However, the value / moral education or character that only reaches the moral feeling alone is not enough, because when it is limited to want or will, without real actions, it only produces hypocritical humans [11].

It should also be realized that the formation of imtaq (faith and piety) and civilization basically includes fostering the beliefs, attitudes, character, and noble values of the nation's culture. These aspects can develop if there are religious and cultural understanding and insight gained from the process of value transfer. In the family and community environment, the process of value transfer takes place more sustainably so that interaction takes place more effectively than what happens in the classroom. In addition to the factors of habituation and exemplification, imtaq guidance and cultivation in the family will also be more successful 
because of the appreciation of religious values result in beliefs, attitudes, behaviors and character, and morals as above [11].

\section{Conclusion}

The result obtained based on research conducted in Magelang, is that the low moral of teenagers at the high school level are honesty, responsibility, and social care.

\section{References}

[1] Mutohar, S. (2013) 'Antisipasi Degradasi Moral di Era Global', Nadwa Jurnal Pendidikan ISlam, 7(2), p. 2013.

[2] Wardi, M. (2012) 'Penerapan Nilai Pendidikan Agama Islam Dalam Perubahan Sosial Remaja', Tadris, VII(1), pp. 31-44.

[3] Yuningsih (2014) 'Menguatkan Kembali Pendidikan Keagamaan Dan Moral Anak Didik', VIII(2), pp. 199-216.

[4] Budiyono, A. (2010) 'Meningkatkan Moralitas Remaja Melalui Dukungan Sosial', Jurnal Dakwah Dan Komunikasi, 4(2), pp. 1-10.

[5] Azmi, N. (2015) 'Potensi Emosi Remaja dan Pengembangannya', Social Horizon: Jurnal Pendidikan Sosial, 2(1), pp. 36-46.

[6] Reza, I. F. (2013) 'Hubungan antara religiusitas dengan moralitas pada remaja di madrasah aliyah (ma)', Humanitas, X(2), pp. 45-58.

[7] Rizal, Y. (2017) 'Perilaku Moral Remaja Dalam Perpektif Budaya', Journal of Multicultural Studies in Guidance and Counseling, 1(1), pp. 35-44.

[8] Subur (2016) 'Peran Pendidikan Agama Islam Dalam Perkembangan Jiwa Remaja', Tarbiyatuna, 7(2), pp. 167-185.

[9] Fahrudin (2014) 'Proses Pendidikan Nilai Moral Di Lingkungan Keluarga Sebagai Upaya Mengatasi Kenakalan Remaja', Jurnal Pendidikan Agama Islam-Ta'lim, 12(1), pp. 41-54.

[10] Maharani, L. (2014) 'Perkembangan Moral Pada Anak', Jurnal Bimbingan dan Konseling, 1(2), pp. 104-109.

[11] Hudi, I. (2017) 'Pengaruh Pengetahuan Moral Terhadap Perilaku Moral Pada Siswa SMP Negeri Kota Pekan Baru Berdasarkan Pendidikan Orangtua', Jurnal Moral Kemasyarakatan, 2(1), pp. $30-44$.

[12] Fitri, N., Safei and Marjuni, H. (2016) 'Pengaruh Sikap Kedisiplinan Dan Kejujuran Peserta Didik Terhadap Hasil Belajar Biologi’, Jurnal Biotek, 4(1), pp. 83-100.

[13] Tarigan, S. K. and Siregar, A. R. (2013) 'Gambaran Penalaran Moral Pada Remaja Yang Tinggal Di Daearh Konflik’, Psikologia, 8(2), pp. 79-88.

[14] Pantja, A. and Wulandari, J. (2012) 'Gambaran Kejujuran Sebagai Landasan Keutamaan Moral Mahasiswa Yang Sudah Pernah Mengambil Mata Kuliah Character Building', Jurnal Humaniora, 3(2), pp. 566-572.

[15] Soenarko, B. and Mujiyati, E. S. (2015) 'Peningkatan Nilai Kepedulian Sosial Melalui Modifikasi Model Pembelajaran Konsiderasi Pada Mahasswa Tingkat I Program Studi PGSD FKIP Universitas Nusantara PGRI Kediri', Efektor, (26), pp. 33-47. 